\section{A Five-year Study on the Effect of Cluster Thinning and Harvest Date on Yield, Fruit Composition, and Cold-hardiness of 'Vidal Blanc' (Vitis spp.) for Ice Wine Production}

\author{
Imed Dami ${ }^{1}$, Said Ennahli, and David Scurlock \\ Department of Horticulture and Crop Science, The Ohio State University, \\ Ohio Agricultural Research and Development Center, 1680 Madison Avenue, \\ Wooster, OH 44691
}

Additional index words. cropload, freezing, total soluble solids, vine balance, vine size, winter injury

\begin{abstract}
The aim of this 5-year study was to investigate the influence of cluster thinning (CT) and harvest date on yield components, fruit composition, and bud cold-hardiness in 'Vidal blanc' (Vitis spp.) grapevines grown in northern Ohio. It is unknown whether delaying harvest of 'Vidal blanc' for ice wine production would impact negatively winterhardiness. 'Vidal blanc' grapevines were cluster-thinned at post-fruit set [EichhornLorenz (EL) Stage 31] to two crop levels by retaining 40 (CT40) and 60 (CT60) clusters per vine. Each crop level was harvested at three dates: normal harvest (HD1), fall harvest (HD2) after the first killing frost, and winter harvest (HD3) corresponding to the typical commercial harvest for ice wine. Generally, and as expected, the high crop level CT60 increased crop weight and cropload and decreased total soluble solids and pH. Delayed harvest decreased crop weight, cluster weight, berry weight, and titratable acidity but increased total soluble solids and $\mathrm{pH}$. Bud cold-hardiness, determined by thermal analysis and after two freezing events, was not different among all treatments. It was concluded that CT40 produced optimum vine size and cropload thus balanced vines. Furthermore, delaying fruit harvest in 'Vidal blanc' for ice wine production in the northeastern United States and Canada improves fruit composition but has no adverse influence on bud cold-hardiness.
\end{abstract}

Cropload (CL), defined as a ratio of crop weight and pruning weight, is an indicator of vine balance between vegetative growth and fruit production (Bravdo et al., 1984, 1985; Dami et al., 2005, 2006; Howell, 2001; Naor et al., 2002). Whereas extensive literature has established the optimum range for Vitis vinifera cultivars, there is little information about hybrids. Optimum CLs fall within a specific range of five to 10 in several vinifera cultivars (Bravdo et al., 1985; Smart et al., 1990). However, CL ratios generally exceed that range in hybrids such as 'Seyval blanc' (Reynolds and Wardle, 1994), 'Chancellor' (Reynolds et al., 1995), and 'Chambourcin' (Dami et al., 2005, 2006). High-yielding hybrid cultivars typically have a propensity to overcrop, resulting in reduced growth and fruit and wine quality. 'Vidal blanc' (Vitis spp.), a French-American hybrid, also belongs

Received for publication 30 July 2013. Accepted for publication 18 Sept. 2013.

We are grateful for the financial support provided by the Department of Horticulture and Crop Science, Ohio Agricultural Research and Development Center, and the Ohio Grape Industries.

${ }^{1}$ To whom reprint requests should be addressed; e-maildami.1@osu.edu.
However, growers of 'Vidal blanc' for ice wine production are concerned about the impact of the high-yielding attributes of 'Vidal blanc' in tandem with delayed harvest on vine health, particularly winter-hardiness. With the exception of an early report on optimum cropping of 'Vidal blanc' (Howell et al., 1987), there is no published information on the impact of delayed harvest of different crop levels on winter-hardiness of 'Vidal blanc' intended for ice wine production. Therefore, it was the aim of this 5-year study to investigate the influence of crop level and harvest date on yield components, fruit composition, and bud cold-hardiness in 'Vidal blanc' grapevines grown in northern Ohio.

\section{Materials and Methods}

'Vidal blanc' grapevines were planted in 1981 at a spacing of $2.44 \times 3.05 \mathrm{~m}$ at the Horticultural Research Unit 2, Ohio Agricultural Research and Development Center in Wooster, $\mathrm{OH}$ [lat. $40^{\circ} 47^{\prime} \mathrm{N}$, long.: $81^{\circ} 55^{\prime} \mathrm{W}$, elevation: $311 \mathrm{~m}$ a.s.1., Wooster silt-loam soil (fine-loamy, mixed, active, mesic Oxyaquic Fragiudalfs)]. Vines were trained to a bilateral cordon at a height of $1.8 \mathrm{~m}$ and were spurpruned to 40 nodes on two- to four-node spurs per vine. The study started in 2004 and pruning was followed by shoot-thinning of all treatments to 40 shoots per vine at $\approx 20 \mathrm{~cm}$ shootlength stage (EL Stage 12; Eichhorn and Lorenz, 1977). Shoot positioning and CT, but not leaf pulling, were conducted at pea-sized berry stage (EL Stage 31; Eichhorn and Lorenz, 1977) to retain 40 (CT40) and 60 (CT60) clusters per vine and the treatments continued on the same vines for 5 years. CT consisted of removing clusters adjacent to the most basal clusters on the shoot (Dami et al., 2006). Treatments were harvested at three dates as follows: 1) normal harvest (HD1) is the typical commercial harvest, at which the time of harvest was determined based on optimum juice composition of the following parameters: total soluble solids (TSS) (20 to $21{ }^{\circ}$ Brix), pH (3.1 to 3.2$)$, and titratable acidity (TA) (9 to $10 \mathrm{~g} \cdot \mathrm{L}^{-1}$ ); 2) fall harvest (HD2) after the occurrence of the first killing fall frost when temperature drops below $0{ }^{\circ} \mathrm{C}$; and 3 ) winter harvest (HD3) corresponding to the typical commercial harvest for ice wine when temperature drops to $-8{ }^{\circ} \mathrm{C}$. Each CT and harvest date (HD) treatments were established on three vines and treatments were arranged as a factorial two $(\mathrm{CT}) \times$ three $(\mathrm{HD})$ completely randomized design with four replications. Nets were installed over treated vines to protect against wildlife predation. Other standard commercial practices of disease, insect, and weed management were used.

At time of harvest, crop weight and cluster number were recorded annually for each vine. A 100-berry sample was collected at random from each treatment, weighed, and crushed in a food strainer and TSS, $\mathrm{pH}$, and TA determined in the juice using standard methodology (Zoecklein et al., 1999). Vine size, expressed as pruning weight per vine, was 
recorded and used to calculate CL (crop weight per vine/pruning weight per vine).

Bud cold-hardiness was determined using thermal analysis as described in Zhang and Dami (2012). Bud collection started in the fall of 2006 and repeated on a biweekly or monthly basis through the spring and the cold-hardiness measurements were repeated through 2009. Canes with basal buds (node one to five) were collected and placed in a cooler with ice packs. Buds were kept at $\approx 4{ }^{\circ} \mathrm{C}$ until ready for the freezing test within $24 \mathrm{~h}$. Buds were excised in the laboratory and were loaded on each thermoelectric module (Melcor, Trenton, NJ) with a total of 24 modules (three dates $\times$ two cluster thinning levels $\times$ four replicates). Simulated freezing tests were conducted in a temperaturecontrolled environmental chamber (Tenny Inc., New Columbia, PA). Temperature was held at $-2{ }^{\circ} \mathrm{C}$ for $1 \mathrm{~h}$ then dropped to $-40{ }^{\circ} \mathrm{C}$ at a rate of $4{ }^{\circ} \mathrm{C} \cdot \mathrm{h}^{-1}$. The mean low temperature exotherm, which corresponds to $50 \%$ bud injury or LT50, was determined as described by Wolf and Pool (1987).

On 25 Jan. 2004 and 17 Jan. 2009, air temperatures dropped to -22.3 and $-28.1{ }^{\circ} \mathrm{C}$, respectively. To take advantage of these natural freezing events and evaluate their effects on treatment responses, a bud injury assessment of 'Vidal blanc' grapevines was conducted. Ten canes with 10 buds (node positions one to 10) per replicate were collected from all treatments after each freezing event. Canes were thawed for a minimum of $48 \mathrm{~h}$ at room temperature, and buds were excised with a razor blade and visually evaluated whether they were dead (brown) or alive (green) and reported as percent of dead buds. Only primary buds were evaluated in 2004 and both primary and secondary buds were evaluated in 2009.

The data were analyzed using the mixed procedure of SAS (SAS Institute, Cary, NC). Means within each treatment were compared by least significant difference test at $P \leq 0.05$.

\section{Results and Discussion}

Effect of cluster thinning and harvest date on yield, pruning weight, and cropload. We were able to achieve two crop levels as the vines thinned to CT60 had a higher cluster number than that of CT40 in 4 of 5 years (Table 1; Fig. 1A). The 5-year mean of clusters per vine in the CT60 was $28 \%$ higher than that in CT40. As a result, the 5-year mean crop weight in CT60 was 13\% higher, but cluster weight was $14 \%$ lower than in CT40 (Table 1; Fig. 1A-B). CT treatment had no effect on berry weight in any season (Table 1; Fig. 1D). Therefore, it is concluded that yield increase was the result of increased cluster number but not cluster weight. Similar observations have been previously reported in other cultivars, suggesting possible yield compensation (Dami et al., 2006; Kliewer and Dokoozlian, 2000; Kurtural et al., 2006; Naor et al., 2002; Reynolds et al., 1986). It is also noted that yield was reduced significantly (27\%) in 2006 as compared with
Table 1. Five-year means of yield components, pruning weight, and cropload of 'Vidal blanc' grapevines in response to cluster thinning (CT) and harvest date (HD).

\begin{tabular}{|c|c|c|c|c|c|c|}
\hline Treatment ${ }^{z}$ & $\begin{array}{l}\text { Actual clusters } \\
\text { per vine }\end{array}$ & $\begin{array}{l}\text { Crop wt per } \\
\text { vine }(\mathrm{kg})\end{array}$ & $\begin{array}{l}\text { Cluster } \\
\text { wt (g) }\end{array}$ & $\begin{array}{l}\text { 100-berry } \\
\text { wt (g) }\end{array}$ & $\begin{array}{l}\text { Pruning wt per } \\
\text { vine }(\mathrm{kg})\end{array}$ & Cropload \\
\hline \multicolumn{7}{|c|}{$\begin{array}{l}\text { Cluster thinning, } \\
\text { crop level (CL) } \\
\text { (clusters per vine) }\end{array}$} \\
\hline СТ60 & $59 \mathrm{a}^{\mathrm{x}}$ & $12.3 \mathrm{a}$ & $212 \mathrm{~b}$ & $215 \mathrm{a}$ & $0.67 \mathrm{~b}$ & $24 \mathrm{a}$ \\
\hline CT40 & $46 \mathrm{~b}$ & $10.9 \mathrm{~b}$ & $241 \mathrm{a}$ & $216 \mathrm{a}$ & $0.77 \mathrm{a}$ & $18 \mathrm{~b}$ \\
\hline \multicolumn{7}{|c|}{ Harvest date (HD) } \\
\hline HD1 & $54 \mathrm{a}$ & $12.1 \mathrm{a}$ & $227 \mathrm{a}$ & $215 \mathrm{a}$ & $0.70 \mathrm{a}$ & $23 \mathrm{a}$ \\
\hline HD2 & $52 \mathrm{a}$ & $11.3 \mathrm{a}$ & $217 \mathrm{a}$ & $219 \mathrm{a}$ & $0.75 \mathrm{a}$ & $21 \mathrm{a}$ \\
\hline HD3 & $50 \mathrm{a}$ & $10.1 \mathrm{~b}$ & $195 \mathrm{~b}$ & $202 \mathrm{~b}$ & $0.78 \mathrm{a}$ & - \\
\hline $\mathrm{CT}^{\mathrm{w}}$ & ** & $* *$ & ** & NS & * & ** \\
\hline $\mathrm{HD}$ & NS & ** & * & ** & NS & NS \\
\hline $\mathrm{CT} \times \mathrm{HD}$ & NS & $*$ & * & NS & NS & - \\
\hline
\end{tabular}

${ }^{\mathrm{z}} \mathrm{CT} 40=$ vines thinned to 40 clusters per vine; $\mathrm{CT} 60=$ vines thinned to 60 clusters per vine; $\mathrm{HD} 1=$ normal harvest; HD2 = fall harvest; HD3 = winter harvest.

${ }^{y}$ Cropload $=$ crop weight $/$ pruning weight.

${ }^{x}$ Means followed by the same letter are not significantly different by least significant difference test at $P \leq 0.05$.

${ }^{\mathrm{N}} \mathrm{NS},{ }^{*}, * *, * * *$ Nonsignificant or significant at $P \leq 0.05,0.01$, or 0.001 , respectively.
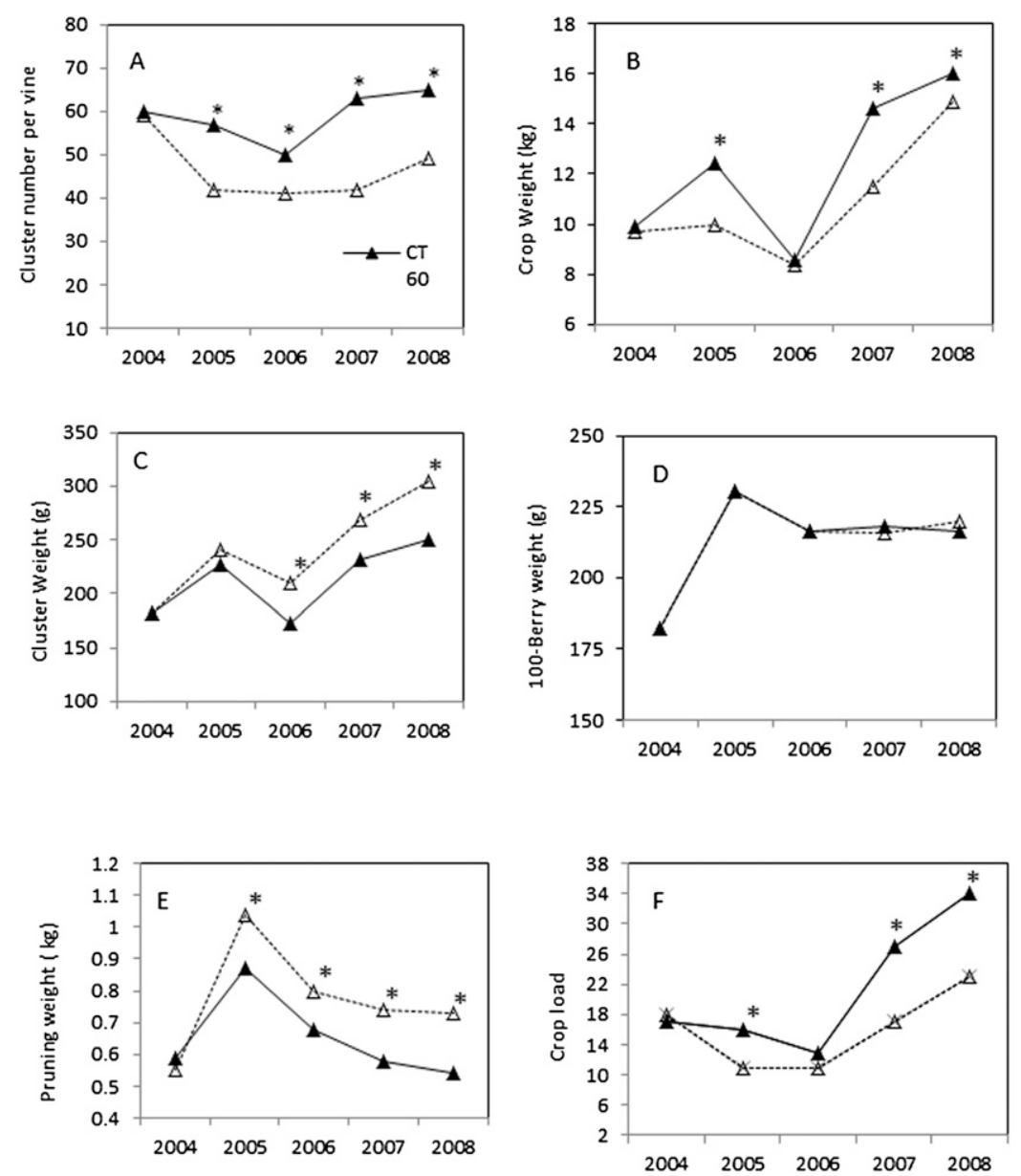

Fig. 1. Effect of cluster thinning on yield components in 'Vidal blanc' grapevines (2004-08): (A) cluster number per vine, (B) crop weight per vine, $(\mathbf{C})$ cluster weight, (D) 100-berry weight, (E) pruning weight per vine, and (F) cropload. CT40 $=$ vines thinned to 40 clusters per vine; CT60 $=$ vines thinned to 60 clusters per vine.

the 5-year mean as a result of a reduction of cluster number per vine (13\%) and cluster weight (19\%) but not berry weight (Fig. 1B). The changes in yield components were attributed to a late spring frost event when air temperature dropped to $-2.7^{\circ} \mathrm{C}$ on $26 \mathrm{Apr}$. 2006 , corresponding to the time of bud burst. Although shoots were not fully emerged, bud damage must have occurred at the bud swell stage (Dami, 2006). 
The 5-year mean harvest dates and respective growing degree-days (GDD, base $\left.10{ }^{\circ} \mathrm{C}\right)$ were as follows: HD1: 6 Oct. (1523 GDD); HD2: 31 Oct. (1567 GDD); and HD3: 16 Dec. (1567 GDD). Despite netting, there was a significant crop loss in 2004 and 2006 as a result of wildlife predation of vines from the HD3 treatment. Thus, data from HD3 in those years were not included. Retaining clusters on the vines for an extended period of time resulted in a decrease of yield per vine and cluster and berry weights in HD3 (Table 1). Yield and cluster weight reduction in HD3 can be attributed to berry dehydration. No differences were observed between HD1 and HD2 (Table 1). There are interactions between CT and HD on yield components; and they are explained by the fact that HD3 and CT40 almost always affected negatively the yield components.

Vine size in CT40 treatment was higher than that in CT60 in 4 of 5 years (Table 1; Fig. 1E). When expressed per meter of cordon, pruning weight in CT40 was consistently highest during the 5-year study averaging $0.32 \mathrm{~kg} \cdot \mathrm{m}^{-1}$ of cordon length, whereas CT60 averaged $0.26 \mathrm{~kg} \cdot \mathrm{m}^{-1}$. Previous research showed that, in a cool climate, optimum vine size falls within the range of 0.3 to $0.6 \mathrm{~kg} \cdot \mathrm{m}^{-1}$, which indicates that vines are balanced (Smart and Robinson, 1991). Based on this study's findings and the published pruning weight range, it is concluded that the CT40 but not CT60 treatment produced balanced vines. Actually, vine size of the latter declined steadily since 2005 (Fig. 1E). The combination of out-of-range and declining pruning weights is an indication that vines were overcropped and out of balance. The literature indicates various responses of pruning weight to CT; whereas some authors reported an increase in pruning weights (Bravdo et al., 1985), others observed no effect on pruning weight after CT (Kurtural et al., 2006; Naor et al., 2002; Reynolds and Wardle, 1994). Dami et al. (2006) observed that only a low crop level (10 clusters per vine) in 'Chambourcin' resulted in optimum pruning weight, whereas high crop levels (20 and 30 clusters per vine) led to overcropping and low vigor situations. In this study, CT but not harvest date affected pruning weight of 'Vidal blanc' (Table 1).

As expected, CL decreased with severe $\mathrm{CT}$ in 3 of 5 years (Table 1; Fig. 1F). A range of CL between five and 10 is considered ideal and produced balanced vines with optimum wine quality in $V$. vinifera cultivars (Bravdo et al., 1985; Kliewer and Dokoozlian, 2000; Smart and Robinson, 1991). CL values above 10 originate from overcropped and thus unbalanced vines except for hybrid cultivars. CL ratios generally exceed that range in hybrids such as in 'Seyval blanc' (Reynolds and Wardle, 1994), 'Chancellor' (Reynolds et al., 1995), and 'Chambourcin' (Dami et al., 2005, 2006) with optimum ranges of 18 to 28,10 to 28 , and five to 14 , respectively. In this study, we identified an optimum CL derived from the CT40 treatment, because only those vines produced optimum vine size over the 5-year duration of the study. In other words, the
CT40 treatment yielded balanced vines. The corresponding 5-year mean of CL ratio was 18 (range, 11 to 23) (Table 1). However, the 5 -year mean CL ratio of 24 (range, 13 to 34 ) from the CT60 was considered high and

indicated vines were overcropped and thus not balanced (Table 1). Previous reports on 'Vidal blanc' identified an optimum CL within a similar range found in this study (Ferree et al., 2003; Howell et al., 1987). CL was

Table 2. Five-year means of total soluble solids, $\mathrm{pH}$, and titratable acidity of 'Vidal blanc' berry juice in response to cluster thinning (CT) and harvest date (HD).

\begin{tabular}{lccc}
\hline Treatment $^{\mathrm{z}}$ & Total soluble solids $\left({ }^{\circ}\right.$ Brix) & $\mathrm{pH}$ & Titratable acidity $\left(\mathrm{g} \cdot \mathrm{L}^{-1}\right)$ \\
\hline $\begin{array}{l}\text { Cluster thinning (CT) } \\
\text { (clusters per vine) }\end{array}$ & & & \\
CT60 & $22.7 \mathrm{~b}^{\mathrm{y}}$ & $3.21 \mathrm{~b}$ & $9.9 \mathrm{a}$ \\
CT40 & $23.4 \mathrm{a}$ & $3.24 \mathrm{a}$ & $9.8 \mathrm{a}$ \\
& & & \\
Harvest date (HD) & & & \\
HD1 & $21.4 \mathrm{c}$ & $3.14 \mathrm{c}$ & $10.3 \mathrm{a}$ \\
HD2 & $22.9 \mathrm{~b}$ & $3.22 \mathrm{~b}$ & $9.9 \mathrm{~b}$ \\
HD3 & $25.2 \mathrm{a}$ & $3.38 \mathrm{a}$ & $8.2 \mathrm{c}$ \\
& & & \\
CT & $* * *$ & $* *$ & NS \\
HD & $* *$ & $* *$ & $* *$ \\
CT $\times$ HD & $* *$ & $* *$ & NS \\
\hline
\end{tabular}

${ }^{\mathrm{z}} \mathrm{CT} 40=$ vines thinned to 40 clusters per vine; $\mathrm{CT} 60=$ vines thinned to 60 clusters per vine; $\mathrm{HD} 1=$ normal harvest; HD2 = fall harvest; HD3 = winter harvest.

${ }^{y}$ Means followed by the same letter are not significantly different by least significant difference test at $P \leq 0.05$.

${ }^{\mathrm{x} S \mathrm{~S},}{ }^{*},{ }^{* *}, * * *$ Nonsignificant or significant at $P \leq 0.05,0.01$, or 0.001 , respectively.
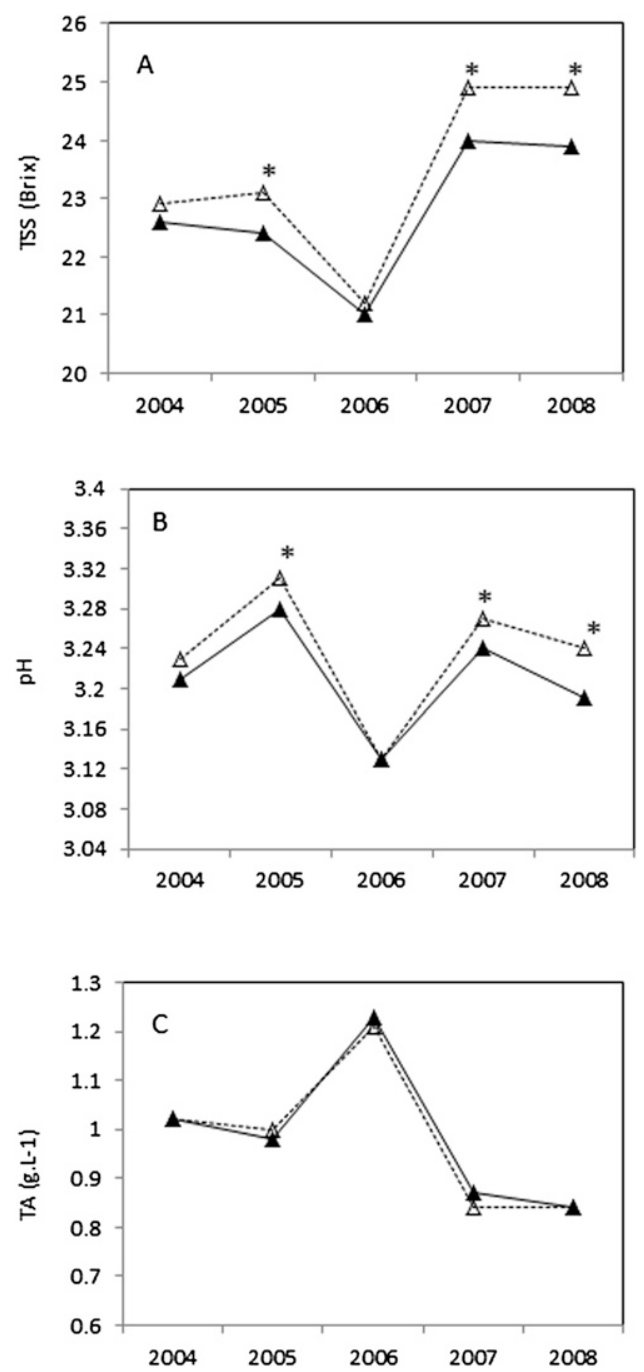

Fig. 2. Effect of cluster thinning on fruit composition in 'Vidal blanc' grapevines (2004-08): (A) total soluble solids (TSS), (B) $\mathrm{pH}$, and (C) titratable acidity (TA). CT40 $=$ vines thinned to 40 clusters per vine; $\mathrm{CT} 60=$ vines thinned to 60 clusters per vine. 
unaffected by harvest date however (Table 1). CL for HD3 treatment was not computed because its value would be meaningless because changes of the ratio at this time were caused by yield reduction resulting from berry dehydration rather than other physiological responses. Based on crop weight, pruning weight, and CL ratios, it is concluded that the CT40 produced balanced vines.

Effect of cluster thinning and harvest date on fruit composition. The CT40 treatment increased TSS and $\mathrm{pH}$ as compared with CT60 over the 5 -year period (Table 2). The CT40 treatment had higher TSS and $\mathrm{pH}$ values than CT60 treatment in 3 of 5 years (Fig. 2AB). However, CT had no effect on TA across the five seasons (Table 2; Fig. 2C). The changes in fruit composition associated with CT have been reported in other grape cultivars and has been explained as a typical response of advancing fruit maturity by reducing the crop level and vice versa (Dami et al., 2006; Guidoni et al., 2002; Kliewer and Dokoozlian, 2000; Kurtural et al., 2006; Naor et al., 2002). Furthermore and expectedly, as harvest is delayed, the TSS increased with HD1 having the lowest and HD3 the highest TSS or an increase of $18 \%$ (Table 2). Although delayed harvest increased $\mathrm{pH}$ in a similar manner as in TSS, TA decreased over the 5 -year study (Table 2). These responses were also generally attributed to more ripe fruit with delayed harvest, which typically produces fruit with high TSS and $\mathrm{pH}$ and low TA (Iland and Coombe, 1988). There are interactions between CT and HD for TSS and $\mathrm{pH}$ but not TA as a result of the combination of severe CT (CT40 treatment) and delayed harvest (HD2 and HD3) resulting in more mature fruit with high TSS and $\mathrm{pH}$ (Table 2).

Effect of cluster thinning and harvest date on cold-hardiness. During this study period, cold-hardiness findings were similar over four seasons. To avoid redundancy, coldhardiness results of only one dormant season (Aug. 2007 to Apr. 2008) are presented. During that time period, the coldest temperature recorded was $-18.3{ }^{\circ} \mathrm{C}$ on $21 \mathrm{Feb}$. 2008. Cold-hardiness measured as LT50 reached $-28.6{ }^{\circ} \mathrm{C}$ at that time (Fig. 3). In other words, there was no winter injury experienced in that year because LT50 was lower than the coldest air temperature recorded. $\mathrm{CT}$ and HD did not have any effect on 'Vidal blanc' bud cold-hardiness in any of the dates measured from fall through spring (Fig. 3). However, in Jan. 2004 and 2009, the extreme minimum air temperatures caused bud injury in all treatments. In 2004, primary bud injury ranged between $34 \%$ and $57 \%$ but was not different among all treatments (Table 3). Similarly, in 2009, primary and secondary bud injury was $39 \%$ to $49 \%$ and $14 \%$ to $18 \%$, respectively, but was not different either (Table 3). Therefore, the findings from the natural freezing events were similar to the simulated freezing tests indicating that coldhardiness was unaffected by CT or HD. It is also worth noting that the primary bud injury averaged $42 \%$ in 2004 and $44 \%$ in 2009
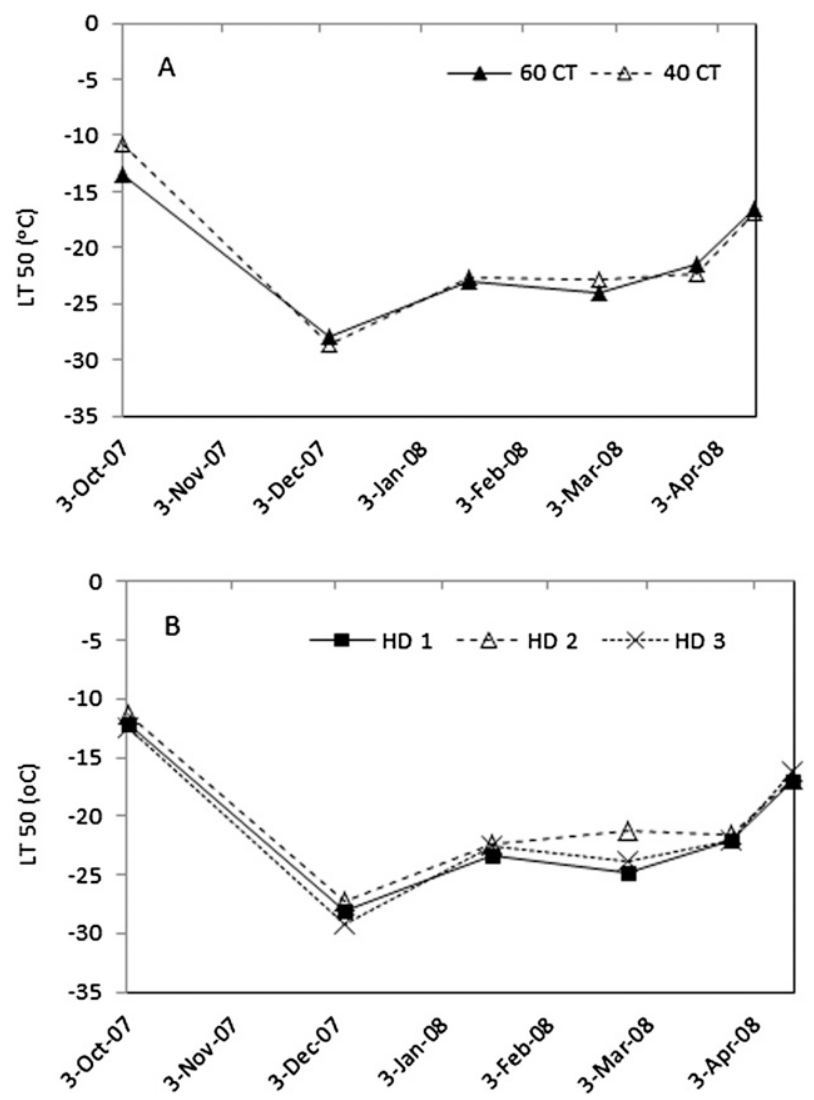

Fig. 3. Effect of (A) cluster thinning and (B) harvest date on cold-hardiness in 'Vidal blanc' grapevines in 2007-08. CT40 = vines thinned to 40 clusters per vine; CT60 = vines thinned to 60 clusters per vine; $\mathrm{HD} 1=$ normal harvest; HD2 = fall harvest; HD3 = winter harvest.

Table 3. Bud winter injury in 'Vidal blanc' grapevines after freezing events in 2004 and 2009.

\begin{tabular}{|c|c|c|c|}
\hline & 2004 & 2009 & 2009 \\
\hline Treatment $^{z}$ & $\overline{\text { Primary bud injury (\%) }}$ & $\overline{\text { Primary bud injury (\%) }}$ & $\overline{\text { Secondary bud injury (\%) }}$ \\
\hline \multicolumn{4}{|c|}{$\begin{array}{l}\text { Cluster thinning (CT) } \\
\text { (clusters per vine) }\end{array}$} \\
\hline CT60 & 40 & 49 & 18 \\
\hline CT40 & 44 & 39 & 14 \\
\hline \multicolumn{4}{|c|}{ Harvest date (HD) } \\
\hline HD1 & 34 & 41 & 14 \\
\hline HD2 & 57 & 45 & 16 \\
\hline HD3 & 35 & 46 & 18 \\
\hline $\mathrm{CT}^{\mathrm{y}}$ & NS & NS & NS \\
\hline HD & NS & NS & NS \\
\hline $\mathrm{CT} \times \mathrm{HD}$ & NS & NS & NS \\
\hline
\end{tabular}

${ }^{{ }^{2} \mathrm{CT} 40}=$ vines thinned to 40 clusters per vine; $\mathrm{CT} 60=$ vines thinned to 60 clusters per vine; $\mathrm{HD} 1=$ normal harvest; HD2 = fall harvest; HD3 = winter harvest.

${ }_{\mathrm{NS}}, *, * *, * * *$ Nonsignificant or significant at $P \leq 0.05,0.01$, or 0.001 , respectively.

although 2009 was much colder $\left(-28.1^{\circ} \mathrm{C}\right)$ than $2004\left(-22.3^{\circ} \mathrm{C}\right)$. It is suggested that cold acclimation conditions were more favorable for maximum cold-hardiness in 2009 than in 2004 when temperatures fluctuated and reached $15^{\circ} \mathrm{C}$ a few days before the freezing event (Dami, 2009). Thus, vines likely deacclimated and were less hardy in Jan. 2004 than in 2009. In summary, our results agree with findings reported by Wample and Wolf (1996) and Wolf (2004) indicating no effect of crop level on cold-hardiness. However, a recent report by Dami et al. (2005) showed a positive effect of CT on cold-hardiness in
'Chambourcin'. It is suggested that the effect of CT on cold-hardiness depends on the variety and its vegetative and reproductive characteristics (i.e., tendency for excessive vigor and/or overcropping) as well as the environment where it is grown. Harvest date has also been investigated on its influence on cold-hardiness in other grape cultivars and showed no effect of delayed harvest on coldhardiness (Hamman et al., 1996; Wample and Barry, 1992). In this study, we found a similar "no response" as previously reported.

In conclusion, the yield and fruit composition responses to $\mathrm{CT}$ and $\mathrm{HD}$ were typical 
of those observed in other grape cultivars. The CT60 is considered not ideal as a result of the decline of vine size over time, yet vines from that treatment showed similar coldhardiness as in CT40. Although that is the case during this 5-year study, it is unlikely that the CT60 is sustainable over the years. In a previous study, it was demonstrated that overcropped (i.e., unbalanced) 'Chambourcin' grapevines declined in vine size over the years and resulted in increased winter injury incidence and vine death (Dami et al., 2006). It was concluded that CT40 treatment produced optimum vine size and CL thus balanced vines. Furthermore, delaying fruit harvest in 'Vidal blanc' for ice wine production in the northeastern United States and Canada improves fruit composition but has no adverse influence on bud cold-hardiness.

\section{Literature Cited}

Bravdo, B., Y. Hepner, C. Loinger, S. Cohen, and H. Tabacman. 1984. Effect of crop level on growth, yield and wine quality of a high yielding Carignane vineyard. Amer. J. Enol. Viticult. 35:247-252.

Bravdo, B., Y. Hepner, C. Loinger, S. Cohen, and H. Tabacman. 1985. Effect of crop level and crop load on growth, yield, must and wine composition and quality of Cabernet Sauvignon. Amer. J. Enol. Viticult. 36:125-131.

Dami, I.E. 2006. Frost damage in $\mathrm{OH}$ vineyards. Ohio Grape-Wine Electronic Newsletter 4:1-4.

Dami, I.E. 2009. Update on the recent freezing events in Ohio. Ohio Grape-Wine Electronic Newsletter 3:2-5.

Dami, I.E., D.C. Ferree, S.K. Kurtural, and B.H. Taylor. 2005. Influence of cropload on 'Chambourcin' yield, fruit quality, and winter hardiness under midwestern United States environmental conditions. Acta Hort. 689: 203-208.

Dami, I.E., D.C. Ferree, A. Prajitna, and D.M. Scurlock. 2006. A five-year study on the effect of cluster thinning on yield, and fruit composition of 'Chambourcin' grapevines. HortScience 41:586-588.

Eichhorn, K.W. and D.H. Lorenz. 1977. Phenological development stages of the grapevine. Nachrichtenbl. Dt. Pflanzenschutzd. 29:119120.

Ferree, D.C., G.A. Cahoon, D.M. Scurlock, and M.V. Brown. 2003. Effect of time of cluster thinning grapevines. Small Fruit Reviews. 2:314.

Guidoni, S., P. Allara, and A. Schubert. 2002. Effect of cluster thinning on berry anthocyanin composition of Vitis vinifera cv. Nebbiolo. Amer. J. Enol. Vitic. 53:224-226.

Hamman, R.A., I.E. Dami, T.M. Walsh, and C. Stushnoff. 1996. Seasonal carbohydrate changes and cold hardiness of Chardonnay and Riesling grapevines. Amer. J. Enol. Viticult. 47: 31-36.

Howell, G.S. 2001. Sustainable grape productivity and the growth-yield relationship: A review. Amer. J. Enol. Viticult. 52:165-174.

Howell, G.S., T.K. Mansfield, and J.A. Wolpert. 1987. Influence of training system, pruning severity, and thinning on yield, vine size and fruit quality of 'Vidal blanc' grapevines. Amer. J. Enol. Viticult. 38:105-112.

Iland, P.G. and B.G. Coombe. 1988. Malate, tartrate, potassium, and sodium in flesh and skin of Shiraz grapes during ripening: Concentration and compartmentation. Amer. J. Enol. Viticult. 39:71-76.

Jackson, D.I. and P.B. Lombard. 1993. Environmental and management practices affecting grape composition and wine quality- $\mathrm{A}$ review. Amer. J. Enol. Viticult. 44:409-430.

Kliewer, W.M. and N.K. Dokoozlian. 2000. Leaf area/crop weight ratios of grapevines: Influence on fruit composition and wine quality. Proc. ASEV 50 $0^{\text {th }}$ Anniversary Annual Meeting, Seattle, WA, 19-23 June. p. 285-295.

Kurtural, S.K., I.E. Dami, and B.H. Taylor. 2006. Effects of pruning and cluster thinning on yield and fruit composition of 'Chambourcin' grapevines. HortTechnology 16:233-240.

Naor, A., Y. Gal, and B. Bravdo. 2002. Shoot and cluster thinning influence vegetative growth, fruit yield, and wine quality of 'Sauvignon blanc' grapevines. J. Amer. Soc. Hort. Sci. 127:628-634.

Reynolds, A.G., R.M. Pool, and L.R. Mattick. 1986. Effect of shoot density and crop control on growth, yield, fruit composition and wine quality of 'Seyval blanc' grapes. J. Amer. Soc. Hort. Sci. 111:55-63.

Reynolds, G.A. and D.A. Wardle. 1994. Impact of training system and vine spacing on vine performance and berry composition of Seyval blanc. Amer. J. Enol. Viticult. 45:444-451.

Reynolds, G.A., D.A. Wardle, and A.P. Naylor. 1995. Impact of training system and vine spacing on vine performance and berry composition of Chancellor. Amer. J. Enol. Viticult. 46:88-97.

Smart, E.R., J.K. Dick, I.M. Gravett, and B.M. Fisher. 1990. Canopy management to improve grape yield and wine quality principles and practices. S. Afr. J. Enol. Vitic. 11:3-17.

Smart, R. and M. Robinson. 1991. Sunlight into wine: A handbook for winegrape canopy management. 1st Ed. Winetitles, Adelaide, Australia.

Wample, R.L. and A. Barry. 1992. Harvest date as a factor in carbohydrate storage and cold hardiness of Cabernet Sauvignon grapevine. J. Amer. Soc. Hort. Sci. 117:32-36.

Wample, R.L. and T.K. Wolf. 1996. Practical considerations that impact vine cold hardiness, p. 22-38. In: Henick-Kling, T., et al. (eds.). Proc. for the Fourth International Symposium on Cool Climate Enology and Viticulture. N.Y. State Agric. Exper. Stat., Geneva, NY.

Wolf, T.K. 2004. Crop yield effect on cold hardiness of Cabernet Sauvignon dormant buds. Acta Hort. (ISHS) 640:177-187.

Wolf, T.K. and R.M. Pool. 1987. Factors affecting exotherm detection in the differential thermalanalysis of grapevine dormant buds. J. Amer. Soc. Hort. Sci. 112:520-525.

Zhang, Y. and I.E. Dami. 2012. Foliar application of abscissic acid increases freezing tolerance of field-grown Vitis vinifera Cabernet franc grapevines. Amer. J. Enol. Viticult. 63:377-384.

Zoecklein, B.W., K.C. Fugelsang, B.H. Gump, and F.S. Nury. 1999. Wine analysis and production. 1st Ed. Chapman and Hall, New York, NY. 